\title{
Hygienic assessment of spontaneously fermented raw camel milk (suusa) along the informal value chain in Kenya
}

\author{
Linnet Wanjiru Mwangi ${ }^{1 *}$, Joseph Wafula Matofari ${ }^{1}$, Patrick Simiyu Muliro ${ }^{1}$ and Bockline Omedo Bebe ${ }^{2}$
}

\begin{abstract}
Background: Suusa is a spontaneously fermented milk product from raw camel milk used by the pastoral communities of Northern and Eastern Kenya. The product can be as a result of intentional fermentation at ambient temperature for 3 days where it is prepared by women specifically for home consumption. The product can also result from unintentional fermentation where raw camel milk intended for sale, undergoes coagulation at any node of the informal value chain. Since no heat treatment is involved in preparation, microbial safety and quality of suusa is completely dependent on the raw milk inherent flora and handling practices. Therefore, the aim of this study was to determine the microbiological quality and safety of suusa along the informal value chain in relation to the raw camel milk handling practices. The study was carried out in Isiolo County where production, bulking and cooling of raw camel milk is done and in Nairobi County where there is biggest market for that milk. A total of 59 milk samples were obtained from the production, bulking, cooling and marketing nodes and analysed for, Titratable Acidity (TA), Total Viable Count (TVC), Coliform Count (CC), Spore Count (SC) and Yeast and Moulds Count (YM). The microbial load of TVC, CC and YM, increased significantly $(P<0.05)$ by 1 log increase, while SC increased by 3 log increase from production to market. The lactic acid increased from $0.07 \%$ to $0.23 \%$ for the unintended suusa. The microbial load comprised of 67 \% Gram Negative Rods (GNR), 62 \% Gram Positive Cocci (GPC) and $28 \%$ YM from production, processing and marketing. Hygienic practices in raw camel milk and suusa production potentially expose the product to microbial contamination associated with reduced shelf life and public health concern.

Results: A total of 59 milk samples were obtained from the production, bulking, cooling and marketing nodes and analysed for, Titratable Acidity (TA), Total Viable Count (TVC), Coliform Count (CC), Spore Count (SC) and Yeast and Moulds Count (YM). The microbial load of TVC, CC and YM, increased significantly $(P<0.05)$ by 1 log increase, while SC increased by 3 log increase from production to market. The lactic acid increased from $0.07 \%$ to $0.23 \%$ for the unintended suusa.The microbial load comprised of $67 \%$ Gram Negative Rods (GNR), 62 \% Gram Positive Cocci (GPC) and $28 \%$ YM from production, processing and marketing.

Conclusion: Hygienic practices in raw camel milk and suusa production potentially expose the product tomicrobial contamination associated with reduced shelf life and public health concern.
\end{abstract}

Keywords: Camel milk, Microbial quality, Suusa, Contamination, Value chain, Isiolo

\footnotetext{
* Correspondence: lynmwng@gmail.com

'Department of Dairy and Food Science and Technology, Egerton University,

P.O. Box 536-20115, Egerton, Kenya

Full list of author information is available at the end of the article
} 


\section{Background}

In Kenya, the camel population is approximated to be 3.1 million (Corman et al. 2014). They are all onehumped (Camelus dromedarius), found mainly in the low lands of Northern Kenya. The camel lives in areas not suitable for crop production and where other livestock species can hardly thrive (Noor et al., 2012). Due to its outstanding performance in arid and semi arid areas (ASAL) of northern Kenya, camels play a central role to the livelihoods and culture of nomadic pastoralists (Guliye et al. 2007). They provide milk, meat and means of transport. The camel milk production in Kenya is estimated at 937 thousand tonnes in 2013 (FAOSTAT, 2015) which translates to about US\$107.1 million. This quantity of milk represents about $12 \%$ of the total national Kenyan milk production (Musinga et al. 2008). During prolonged droughts, camel milk may contribute up to $50 \%$ of total nutrient intake by pastoral groups (Wayua et al., 2012). The most popular camel milk product among the pastoral groups is suusa. Suusa is spontaneously fermented raw camel milk. The fermentation is carried out at room temperature ranging from $26-29{ }^{\circ} \mathrm{C}$, for 1-2 days in a gourd (Lore et al., 2005). The product is a white, low-viscosity product with a distinct smoky flavour and astringent taste (Lore et al., 2005). However, due to demand, the gourds have become small to produce the amount needed and the women pastoralists have turned to recycled plastic oil containers. Suusa is prepared by the Borana and Somali communities of North and Eastern Kenya, by storing milk in plastic containers which is allowed to slowly coagulate over a period of 1-3 days.

Spontaneous fermentation of raw milk takes advantage of the action of naturally occurring mixed microflora inherent in the milk in the plastic containers as well as factors such as temperature and $\mathrm{pH}$ provide the necessary selective factors for evolution of lactic acid bacteria (LAB) that impart desirable attributes to the product (Lore et al., 2005).However, suusa production process faces several handicaps; these include unpredictable production environment, unknown microbiology in processing, lack of process control and, unknown toxicological status (Chinyere and Onyekwere, 1996). Under pastoral production of suusa, factors such as unknown udder health, plastic milking and storage containers, milking personnel practices like tying the quarters to prevent suckling by the calf and dusty milking environment, and lack of water may act as points of contamination (Mulwa et al., 2011). During transportation, either by walking, on donkeys or occasionally on open pickups, long distance from milking point to collection or storage point, poor roads and lack of cooling facilities affects the microbial load by providing conditions for rapid multiplication in the milk(Mulwa et al., 2011). At the collection centres, milk from different suppliers is pooled without prior quality control tests and this acts as a source of contamination and affects the safety and quality of the milk (Momanyi and Jenet 2010; Noor et al., 2013). The only test carried out is organoleptic (taste, sight and smell) (Noor et al., 2013) which is insufficient to detect for other detrimental quality and safety issues related to milk. The variables involved the fermentation include lack of heat treatment of the milk, storage at ambient temperature, lack of known culture composition and hence lack of process control which results in a product of variable quality (Eyassu, 2007). The final product is sold in open air markets and this has an effect on the quality of the product. Suusa produced under pastoral environment faces these challenges along the value chain from production to consumption.

This practice of spontaneously fermenting raw camel milk into suusa is highly valued by the pastoral communities for nutritional and cultural reasons. Earlier studies on suusa product have majorly focused on the handling practices (Wayua et al., 2012) and Lactic Acid Bacteria (LABs) responsible for the fermentation (Lore et al., 2005). However, there exists no information on the microbial quality and safety of suusa along the value chain. The aim of this study was to determine the microbiological quality of suusa along the informal value chain with the aim of enhancing food and income security among the pastoral communities.

\section{Methods}

\section{Study site}

The study was carried out in Isiolo County which is camel milk producing area and in Eastleigh, Nairobi County which is a major urban consumption centre for camel milk.Isiolo County is located in Eastern Kenya, approximately $285 \mathrm{~km}$ North of Nairobi. The County is located at coordinates are $0^{\circ} 21^{\prime} 0^{\prime \prime}$ North and $37^{\circ} 35^{\prime} 0^{\prime \prime}$ East and an altitude ranging from 200 to 300 meters above sea level (ASL) although there are some areas in the county that go up to 1000 ASL. Its annual average temperature ranges between 12 and $28{ }^{\circ} \mathrm{C}$ and receives low rainfall ranging between 300 and $500 \mathrm{~mm}$ per year.

\section{Milk handling practices survey}

Semi structured questionnaires were administered to 90 respondents. At production, 30 respondents were purposively selected who comprised of herders, herd owners and transporters. At collection/bulking centres 30 respondents were selected who comprised of cooling hub attendants, traders and consumers. At Nairobi, Eastleigh market 30 respondents were selected who comprised of 
consumers and traders. Focus Group Discussions (FGD) held with women group of 15 members who were randomly selected to represent camel milk producers, herders, milk traders, and consumers at Isiolo and Eastleigh, Nairobi. This was done to identify handling practices along the value chain.

\section{Milk sampling}

Samples of raw camel milk and suusa were collected in triplicates at each representative point of the value chain for microbiological analysis. At production, pooled milk samples from the herds. Milk samples were collected from each container at the herd level and later pooled to make a representative sample of 20. At bulking centres, a total of 12 random samples were collected from each cooling hub. A total of 7 unintended suusa samples were collected at the time of the study while a total of 10 intended suusa were collected. Intended suusa was collected from pastoral women who were requested to prepare it since the commodity is rare. A total of 10 suusa samples were collected from Eastleigh, Nairobi market from 10 traders. Pooled suusa sample was made by pooling milk from as many containers as each woman trader had to obtain a representative sample. At each sampling point, $50 \mathrm{ml}$ of milk sample was taken and transferred into sterile screw-capped sampling bottles, securely capped, clearly labelled and immediately transported to the laboratory for analysis under ice $\left(4^{\circ} \mathrm{C}\right)$. A total of 59 samples were obtained for titratable acidity and microbial analysis.

\section{Sample analysis}

The raw camel milk and suusa samples analysis was done at Egerton University, Food microbiology laboratory. Serial dilution of up to $10^{-6}$ was done using peptone water and $1 \mathrm{ml}$ of homogenate of sample was aseptically transferred into a sterile petri dish. Total Viable Counts (TVC) was enumerated on Plate Count Agar (PCA) (Oxoid, UK) using pour plating method and the plates incubated at $37{ }^{\circ} \mathrm{C}$ for 48 hours. The Coliforms counts (CC) were enumerated on Violet Red Bile Agar (VRBA) (Oxoid, UK) using pour plating technique and plates incubated at $37{ }^{\circ} \mathrm{C}$ for 24 hours(AOAC, 1995). The Spore Counts (SC) were enumerated by heat treating milk samples in a water bath at $80{ }^{\circ} \mathrm{C}$ for 10 minutes and $1 \mathrm{ml}$ of appropriate dilution pour plated on (PCA) (Oxoid, UK) and the plates incubated at $37{ }^{\circ} \mathrm{C}$ for 24 hours (AOAC, 1995). While the yeast and mould were determined on Potato Dextrose Agar (PDA) (Oxoid, UK) by spread plating technique and the plates incubated at $25^{\circ} \mathrm{C}$ for 5 days (AOAC, 1995).

Discrete colonies grown on plates after incuation were selected randomly and purified by repeated plating on the same agar according to Lore et al. (2005). The colonies were then subjected to morphological (cell shape, motility, cell grouping and endospores), biochemical (catalase, oxidase, carbohydrate utilization, indole, and Methyl red-Vosges-Proskauer) and physiological tests and identified to genus level (AOAC, 1995).

Developed acidity in the samples was determined according to the method described by the International Dairy Federation (I.D.F.) (1990). $9 \mathrm{ml}$ of the milk samples were measured into the conical flasks, and $1 \mathrm{ml}$ $0.5 \%$ alcoholic phenolphthalein indicator added then titrating with $0.1 \mathrm{~N}$ sodium hydroxide $(\mathrm{NaOH})$ until a faint pink colour appears. The results were then expressed as \% lactic acid where $1 / 10 \mathrm{ml} \mathrm{NaOH}$ is equal to $0.09 \% \mathrm{w} / \mathrm{v}$ lactic acid.

\section{Statistical analysis of data}

The microbial counts for the total viable count (TVC), coliform count (CC), spore count (SC), yeast and mould count (YM) were transformed to base-10 logarithm of colony forming units (cfus) per millilitre (ml) of the milk samples $\left(\log _{10} \mathrm{cfu} / \mathrm{ml}\right)$. The transformed data was tested for normality using PROC NPAR1WAY procedure of Komolgorov-Smirnoff's test and also tested for homogeneity of variances using Levene's test before assumption of analysis of variance (ANOVA) was done using the General Linear Model (GLM) procedure of SAS version 9.1 (SAS Institute, Inc., Cary, NC). The independent variable was the milk quality and value chain points (production, bulking, processing and marketing). The significance of the means was determined using Tukey's Honestly Significance Difference (HSD) test at $P<0.05$.

\section{Results}

\section{Mapping the suusa value chain}

The value chain for suusa mapped from surveys and FGD is represented in Fig. 1, revealing the handling practices along the value chain. Camels are milked at "boma" (similar to a kraal) by herders. Fresh milk is bought by women groups or individuals to make suusa or sell in open air market. Soured milk is downgraded and sold as unintended suusa. Fresh camel milk and suusa is consumed by both pastoralists and non-pastoralists.

The common camel milk handling practices that influence the contamination levels in milk is shown in Table 1. It was found that all herders neither wash their hands nor wash the camel udder before milking and all camel milk handling containers were plastic. After milking and bulking at the herd level, all milk was found to be transported by the either motorbikes when the herd was near Isiolo town or trucks when the herds were far from the town e.g. from Kulamawe which was about $100 \mathrm{KM}$ form Isiolo town. Isiolo town is the main collection center for raw camel milk where there are cooling facilities for the milk. At Isiolo, milk 


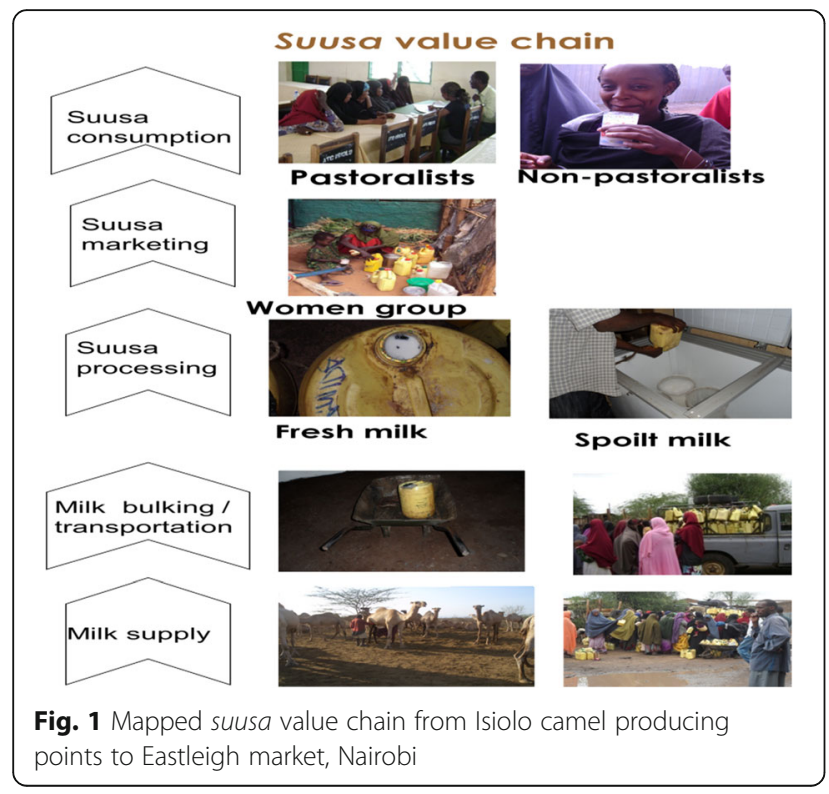

was either transported to Nairobi using Buses or sold in the town through open air vending or milk bars. Of interest was that suusa was made through 2 identified processes. One process is that raw camel milk that gets sour/coagulates on transit to collection or market centres from the production area- Boma would be sold as suusareferred to as unintended suusa by the authors. The fermentation in this case would take from 4-24hours. The other process is intentional spontaneous fermentation of raw camel milk for a period of 3 days mostly done by pastoral women for home consumption referred as intended

Table 1 The common handling practices for the camel milk

\begin{tabular}{lll}
\hline Practice & N & Frequency (\%) \\
\hline Hand washing & 30 & 0 \\
Udder washing & 30 & 0 \\
Plastic milk storage containers & 30 & 100 \\
Means of transport to cooling centres: & 30 & 20 \\
$\quad$ Truck & & 70 \\
$\quad$ Motorbike & & 10 \\
$\quad$ Donkeys & 30 & 0 \\
Means of transport to the market-Nairobi: & & 100 \\
$\quad$ Truck & 30 & 100 \\
$\quad$ Buses & 30 & 0 \\
Non-performance of quality control tests \\
before bulking
\end{tabular}

suusa. However, preparation of suusa through the 2 processes involved no heat treatment or quality control tests before fermentation. Unintended suusa was found to be vended by the roadside $(80 \%)$, sold in the milk bars $(10 \%)$ and also sold in hotels (10\%).

\section{Practices associated with handling of camel milk by the pastoralists}

The challenges faced by the actors along the camel informal milk value chainsthat affect the quality of the milk as identified from the FDGs are shown in Table 2. Sanitation problems were identified as the biggest challenge due to the lack of potable water along the value chain. Lack of milk cooling facilities, interrupted electricity supply where these facilities are available, poor road network to the market, long distance to the market and pooling of milk from different sources were the main challenges identified for the spoilage of milk to unintended suusa.

Microbial load and acidity of suusa along the value chain

Figure 2 shows the microbial load for unintended suusa along the value chain. For unintended suusa, the Total Viable Count (TVC) increased from $\log _{10} 7.79$ at production to $\log _{10} 8.51$ at the market, Coliform Counts (CC) increased from $\log 106.31$ to $\log 107.99$, Spore Count (SC) increased from $\log 104.53$ to $\log 107.56$ and Yeast and Moulds (YM) counts increased from $\log 10$ 4.85 to $\log 105.70 \mathrm{cfu} / \mathrm{ml}$. The microbial load of intended suusa at the production and market levels is shown in Fig. 2. The TVC increased from $\log 107.79$ at production to $\log 108.41$ at the market, CC increased

Table 2 The Challenges faced in the camel milk value chain

\begin{tabular}{ll}
\hline Value chain node & Challenges \\
\hline Production & Lack of water \\
& Lack of cooling facilities \\
& Personal, equipment and environment hygiene \\
& Mixing of milk from diseased camels \\
& Lack of veterinary service due to high mobility \\
& Spoilage/unexpected fermentation \\
& Interrupted power supply to coolers \\
& Pooling milk \\
& Lack of clean water \\
& Lack of quality control tests \\
& Lack of knowledge on hygiene and quality checks \\
& Lack of refrigerated tankers for transporting the milk \\
& Poor state of roads \\
& Sale in open air-roadside \\
Transportation & Long distance to market \\
& Lack of cooling facilities \\
& Spoilage/unexpected fermentation \\
Marketing &
\end{tabular}




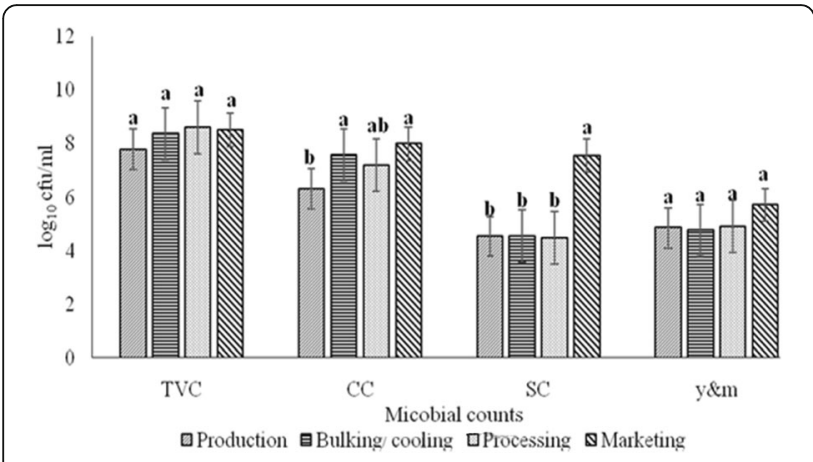

Fig. 2 Microbial load for unintended suusa along the value chain

from $\log 106.31$ to $\log 107.75$, SC increased from $\log 10 \quad 4.53$ to $\log 107.24$ and $\mathrm{YM}$ increased from $\log 104.85$ to $\log 105.41 \mathrm{cfu} / \mathrm{ml}$. The SC was significantly higher at $P<0.05$ for the suusa at the market level than at the production level. Also, the microbial load for the TVC, CC and YM were significantly high in suusa at the market than at the production.

Figure 4 shows the change in developed lactic acid in unintended suusa. Lactic acid increased significantly $(P<0.05)$ along the value chain from 0.07 to $0.23 \%$. The lactic acid (\% LA) for the intended suusa increased from $0.07 \%$ to $0.60 \%$ from production to the market as shown in figure.

\section{Main types of organisms in suusa along the value chain}

Table 3 shows the main type of microorganisms that were isolated from unintended suusa. There was high incidence of Gram negative rods of $67 \%$ from production to the market followed by Gram positive cocci with an incidence of $62 \%$. YM had the least incidence at $28 \%$.

Table 4 shows the main type of microorganisms that were isolated from intended suusa. The incidence of Gram negative rods and gram positive cocci were highest at $60 \%$ and $50 \%$, respectively.

Table 5 shows the different types of microorganisms isolated from the two suusa value chains. Gram negative rods were identified to be E. coli, Pseudomonas and

Table 3 Incidence of Main groups of microorganisms isolated from the unintended suusa

\begin{tabular}{|c|c|c|c|c|c|c|}
\hline Chain node & $\mathrm{N}$ & $\mathrm{G}+$ rods $^{\mathrm{a}}$ & G-rods ${ }^{a}$ & $\mathrm{G}+\mathrm{cocci}^{\mathrm{a}}$ & Spores $^{\mathrm{a}}$ & $Y \& M^{a}$ \\
\hline Production & 10 & 2 & 6 & 7 & 2 & 2 \\
\hline Cooling \bulking & 12 & 6 & 8 & 7 & 3 & 2 \\
\hline Processed product & 7 & 4 & 4 & 4 & 3 & 4 \\
\hline Market & 10 & 8 & 8 & 6 & 5 & 3 \\
\hline Total & 39 & 20 & 26 & 24 & 13 & 11 \\
\hline Incidence (\%) & & 51 & 67 & 62 & 33 & 28 \\
\hline
\end{tabular}

Key: $\mathrm{N}$ is the number of samples; $\mathrm{G}+$ : Gram positive, G-: Gram negative, $Y \& M$ : yeast and moulds: ${ }^{\text {as }}$ the number of positive observed for a specific group of organisms.
Table 4 Incidence of main groups of microorganisms isolated from the intended suusa

\begin{tabular}{lllllll}
\hline Value chain node & $\mathrm{N}$ & G+ rods & G-rods & G+ cocci & Spores & YM \\
\hline Production & 10 & 2 & 5 & 6 & 2 & 2 \\
Processing/marketing & 10 & 3 & 7 & 4 & 3 & 3 \\
Total & 20 & 5 & 12 & 10 & 5 & 5 \\
Incidence & $25 \%$ & $60 \%$ & $50 \%$ & $25 \%$ & $25 \%$ \\
\hline
\end{tabular}

Enterobacter. Gram positive rods included Bacillus and Lactobacillus species while the gram positive cocci included Micrococcus, Streptococcus and Staphylococcus species.

\section{Discussion}

Microbial load and acidity along the suusa value chain Kenya Bureau of Standards (KEBS) regards raw whole camel milk as good when the total viable counts (TVC) are between $0-5 \times 10^{5} \mathrm{cfu} / \mathrm{ml}$ for grade I and II (KEBS, 2007). The raw camel milk at production was above the recommended range and therefore, the milk can be regarded as of poor quality. High TVC at production can be attributed to handling practices like not washing hands before milking, no washing of the camel's udder before milking, use of plastic containers for milking and storage of milk in plastic containers which are not easy to clean. Use of recycled plastic containers which are not easy to clean harbours spoilage microorganisms, unrefrigerated transportation, long distance, poor roads to cooling centres and pooling of milk from different suppliers at the cooling centres are risk factors to the growth and multiplication of the indigenous microflora, resulting in reduction of milk quality and safety (Wayua et al., 2012).There was significant increase $(P<0.0 .5)$ in TVC from production to marketing which is attributed to absence of heat treatment of milk prior to fermentation coupled with spontaneous fermentation. Results agree with those reported by Odongo et al. (2016) and Matofari et al. (2013). The GNR were the most prevalent types of microorganisms for both the intended and unintended suusa while the YM were the least prevalent for both.

Lactic acid increased significantly $(P<0.05)$ from production to the market with no effect on microbial load reduction as shown in Figs. 4 and 5.With fermentation, lactic acid bacteria break down lactose into lactic acid. Presence of GNR which are fermentative organisms had an influence on increased acid content. Intended suusa is fermented over a period of 3 days ( $72 \mathrm{hrs}$ ) and this further explains why the percentage lactic acid was higher than unintended suusa which takes less than 24 hours.

Coliforms increased significantly $(P<0.05)$ from production to the market by $1 \log$ increase as shown in 
Table 5 Types of microorganisms isolated from the suusa value chain

\begin{tabular}{|c|c|c|c|c|c|c|c|c|c|}
\hline Chain node & $\mathrm{N}$ & E. coli & Enterobacter & Pseudomonas & Micrococcus & Staphylococcus & Streptococcus & Bacillus & Yeast and molds \\
\hline Production & 10 & 5 & 6 & - & 5 & 2 & 3 & 2 & 2 \\
\hline Bulking/cooling & 12 & 4 & 4 & 8 & 3 & 2 & 4 & 3 & 2 \\
\hline Processing & 7 & 4 & 4 & - & 2 & 2 & 3 & 3 & 4 \\
\hline Marketing & 10 & 4 & 3 & 2 & 6 & 2 & 2 & 5 & 3 \\
\hline Total & 39 & 17 & 17 & 10 & 16 & 8 & 12 & 13 & 11 \\
\hline Incidence (\%) & & 44 & 44 & 27 & 41 & 21 & 31 & 33 & 28 \\
\hline
\end{tabular}

Key: $\mathrm{N}$ is the number of samples analysed

Figs. 2 and 3. Coliforms are found in the soil, mud, dust, plant materials and can be dispersed into the atmosphere by dust into the product. With natural fermentation, the coliforms will multiply and cause problems in the final product because lactic acid bacteria will initially be very low Gadaga et al. (2004). Coliforms also have adaptation strategies that range from temperature evasions, acid tolerance and production of probiotics like colicins that inhibit growth of other microorganisms (Abee et al. 1995; Gadaga et al., 2004). Occurrence of coliforms more so E.coli in the final product despite high lactic acid (Figs. 4 and 5) is probably due to induced acid tolerance by the organism through production of acid shock proteins which enhance its survival through neutralization of the external environment, adjusting catabolism to the new environment, performing DNA repair and membrane biogenesis and contribute to microbial pathogenesis (Bearson et al., 1997). Karagözlü et al. (2007) found that stationary phase cells of E.coli strains were able to survive and multiply in kefir (Caucasian fermented camel milk). It has also been found to survive in fermented goat milk, amasi (Bearson et al., 1997). Isolation of coliform bacteria along the suusa value chain is an indication of presence of enteric pathogens in the suusa value chain as shown in Table 5. This shows hygienic conditions during handling and processing of camel milk into suusa are low. Suusa therefore has public health risk potential for spread of foodborne illnesses such as Escherichia coli O157:H7 illnesses.

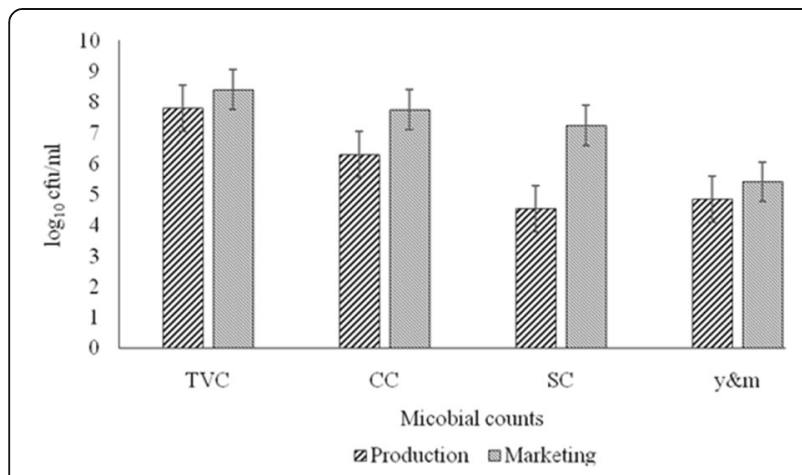

Fig. 3 Microbial load for intended suusa along the value chain
There was a significant $(p<0.05)$ increase in spore counts from production to market samples by $3 \mathrm{log}$ increase as shown in Figs. 2 and 3. Spore forming bacteria are environmental microorganisms such as Bacillus and Clostridium species. At production, they may originate from water used to wash the milking equipment and dust from the milking area. Spore formers like Bacillus cereus display a mechanism of acid tolerance response (ATR) and can survive below $\mathrm{pH} 4.0$ favourable for spore formation (Gadaga et al., 2004). This explains the existence of increased spore forming bacteria in suusa at the market level. Gram positive spore forming rods were identified as Bacilli. High incidence at the market could be attributed to the marketing environment characterised by sale in the open with heaps of waste material, dust and mud close to where the product is sold. Spores are carried by wind into the atmosphere and into the product. Bacilli are aerobic whose typical habitat is soil although they are widely distributed in nature and gain access to milk and suusa through air, water, fodder and feed. Spore-forming bacteria are known to cause food spoilage and food-poisoning by producing heat labile enterotoxins. Therefore, their presence in suusa poses a risk of food poisoning by the enterotoxins to the consumers of the milk product.

Yeast and moulds increased by 1 log increase from production to the marketas shown in Figs. 2 and 3. High contamination by yeasts and moulds may be due to poor

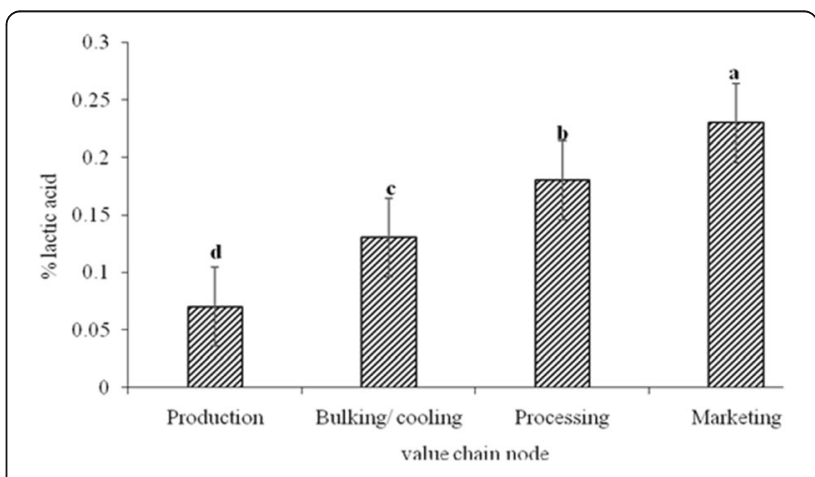

Fig. 4 Lactic acid in unintended suusa along the value chain 


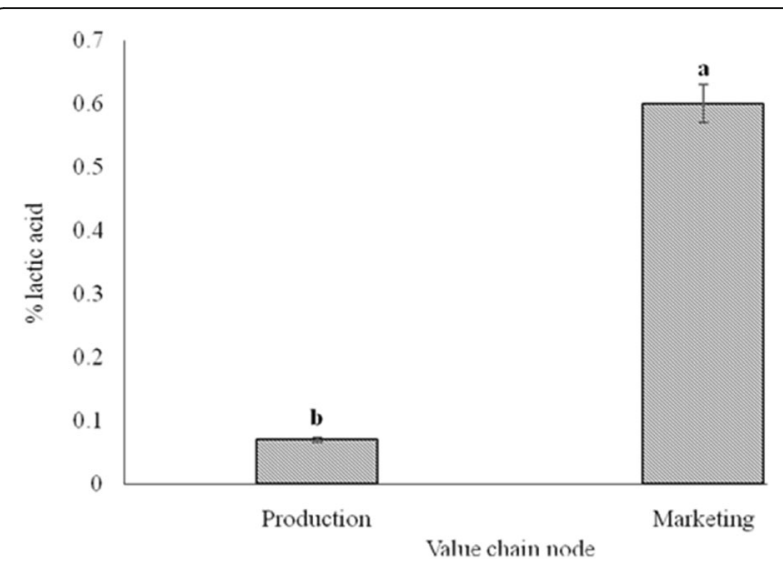

Fig. 5 Lactic acid in intended suusa along the value chain

processing and marketing conditions and uncontrolled fermentation which led to contamination. During spontaneous fermentation of suusa, organic acids such as lactic, acetic and propionic acids are produced which lower the $\mathrm{pH}$. The lower $\mathrm{pH}$ is favourable for growth of yeast and mould species which causes these species to become competitive in the immediate medium (suusa) hence the significant increase $(P<0.05)$ in yeast and mould count in marketed suusa (Lefoka, 2009).

Results in Tables 3 and 4 display the main type of microorganisms that were isolated from intended and un-intended suusa along the value chain. Gram negative rods had the highest incidence of $88 \%$ from production to the market followed by Gram positive cocci with an incidence of $84 \%$. Micrococci were isolated and could account for the high count of Gram positive cocci which is mostly found in water, soil and dust. Yeast and moulds had the least incidence at $28 \%$. Gram negative rods were identified to be E. coli, Pseudomonas and Enterobacter. Presence of E.coli is an indication of faecal contamination by handling from production to the market Rochelle-Newall et al. (2015). This indicates possibility of presence of other enteric pathogens. Gram positive spore forming rods were identified as Bacillus and the high incidence at the market could be attributed to the environment in which the product is produced and sold. The environment was characterised by heaps of waste material, dust and mud and this could be the source of the spores which are carried into the atmosphere and into the product.

Gram positive cocci isolated from camel milk and suusa included Streptococcus and Micrococcus species. Streptococcus species especially the Streptococcus lactis group originate from equipment that is contaminated due to insufficient sanitation. Organisms like Micrococci, coliforms and enteric pathogens originate from hand milking and milk handling that might contaminate the milk via the skin, nose and mouth(Cui et al., 2016). Risk factors identified in the field of study that have contributed to the specific organisms associated with suusa were: not washing hands or camels' udder before milking, dusty milking environment, use of organoleptic tests for quality assessment of milk, bulking milk from different suppliers, use of not easy to clean plastic containers, delayed milk delivery, lack of refrigeration during transport and sale of suusa in open air markets (Noor et al., 2013). Other authors (Akweya et al. 2012; Wanjohi et al. 2010) have also detected Staphylococcus aureus, in camel milk.

Spores of Bacillus species as well as the organism were also detected. The genus Bacillus are typical habitats of the soil and are widely distributed in nature and may gain access to milk and dairy products through the air, water, fodder and feed thereby present on the skin and hair of cattle (Loralyn and Robert, 2009). Bacillus species produce heat stable protease and lipase which may eventually cause spoilage to camel milk and milk products (Samaržija et al. 2012). Other species such as Bacillus cereus produce toxins which lead to food intoxication from ingestion of contaminated food. Presence of the Bacillus species in camel milk makes the food a potential risk to consumers. Spores increased significantly $(P<0.05)$ along the value chain in Fig. 2. This is attributed to handling practices observed along the value chain that have led to contamination of both raw and fermented product. Risk factors identified include: dusty milking environment, use of plastic milking and storage containers and unrefrigerated transport of raw milk from production to cooling centres. These factors most probably led to the growth and multiplication of spore forming bacteria hence high counts.

Among the major isolates of the microorganisms was the Pseudomonas species. Pseudomonas species produce heat stable proteases and lipases keeping their activity even after pasteurization thereby producing off-flavours in milk as well sweet curdling of pasteurized milk (Perko, 2011). Pseudomonas species are the main psychrotrophic bacteria isolated from refrigerated raw milk, being among the major spoilage agents in the dairy industry (Paula Ana et al. 2011). Presence of the genus Pseudomonas indicates improper cooling and refrigeration of camel milk.

\section{Conclusions}

Handling practices along the suusa value chain influences microbial load and consequently, contributes to spoilage of camel milk and suusa. Extension, training and regular monitoring to improve handling practices along the suusa value chain is essential. Statutory (legal) institutions like Kenya Bureau of Standards need to address handling practices of camel milk and milk products along the chain to improve safety, quality and acceptability hence better 
market. As a consequence of lack of process control in suusa fermentation, the microbial diversity in the product is uncontrolled. Suusa has presence of high loads of microorganisms of safety concern. More in depth studies on suusa are needed to quantify and identify organisms of safety concern to the species level using molecular techniques.

\section{Abbreviations \\ ANOVA: Analysis of Variance; CC: Coliform Count; FGD: Focus Group Discussions; GLM: General Linear Model; GNR: Gram Negative Rods; GPC: Gram Positive cocci; HSD: Honest Significant Difference; KEBS: Kenya Bureau of Standards; LAB: Lactic Acid Bacteria; LSD: Least Significant Difference; NC: North Carolina; PCA: Plate Count Agar; PDA: Potato Detrose Agar; RUFORUM: Regional Universities Forum for capacity building in Agriculture; SAS: Statistical analysis software; SC: Spore count; TA: Titratable acidity; TVC: Total viable count; UK: United Kingdom; VRBA: Violet red bile agar; YM: Yeast and Molds}

\section{Acknowledgements}

The authors acknowledge the women group of Isiolo County for availing samples and participating in the study. Acknowledgement also goes to Steven Wakoli and Pauline Madete for their assistance in sample collection. We also acknowledge Dr. Olivier Kashongwe for assistance in data analysis as well Mr. Nobert Wafula for the invaluable assistance in the editing of the manuscript.

\section{Funding}

This research work was financially supported by Regional Universities Forum for Capacity Building in Agriculture (RUFORUM) under research grant number RU2011GRG11 titled: Consumer and regulator concerns about pastoral indigenous knowledge food processing: participatory analysis for producers' and consumers' benefits in Kenya.

\section{Authors' contributions}

This research work was part of LM Thesis research for the award of MSc. Food Science degree of Egerton University and supervised by JM, PM and BB. LM was in-charge of FGDs and questionnaire administration, samples collection and analysis under the guidance and supervision of the three supervisors. All the authors were involved in the designing of the experiment, data analysis, interpretation of the results and manuscript drafting. All authors read and approved the final manuscript.

\section{Authors' information}

Ms. Linnet Mwangi was a graduate Student in the Department of Dairy and Food Science and Technology in Egerton University, Kenya, undertaking MSc. Food Science. Ms. Mwangi has a BSc. Food Science and Technology and MSc in Food Science from the same university. She has several years of working experience in the dairy and food manufacturing industries in Kenya. Prof. Joseph Matofari is an associate professor and Dr. Patrick Muliro is a senior lecturer in the Department of Dairy and Food Science and Technology in Egerton University while Prof. Bockline Bebe is a professor at the of Department of Animal Science, Egerton University, Kenya.

\section{Competing interests}

Authors of this research article declare that they don't have any financial or non-financial competing interests.

\section{Author details}

${ }^{1}$ Department of Dairy and Food Science and Technology, Egerton University, P.O. Box 536-20115, Egerton, Kenya. ${ }^{2}$ Department of Animal Sciences, Egerton University, P.O. Box 536-20115, Egerton, Kenya.

Received: 5 August 2016 Accepted: 11 October 2016 Published online: 18 October 2016

\section{References}

Abee TL, Krokel L, Hill C. Bacteriocins: Modes of action and potentials in food preservation and control of food poisoning. Int J Food Microbiol. 1995;28:169-85.
Akweya BA, Gitao CG, Okoth MW. The acceptability of camel milk and milk products from north eastern province in some urban areas of Kenya. Afr J Food Sci. 2012;6(19):465-73.

Bearson S, Bearson B, Foster JW. Acid stress responses in enterobacteria. FEMS Microbiol Lett. 1997;147:173-80.

Chinyere II, Onyekwere SE. Nigerian indigenous fermented foods: their traditional process operation, inherent problems, improvements and current status. Food Res Int. 1996;29:527-40.

Corman VM, Jores J, Myer B, Younan M, Liljander A, Said MY. Antibodies against MERS Coronavirus in dromedary camels, Kenya, 1992-2013. Emerg Infect Dis. 2014;20:1319-22.

Cui $H$, Zhou H, Lin L. The specific antibacterial effect of the Salvia oil nanoliposomes against Staphylococcus aureus biofilms on milk container. Food Control. 2016;61:92-8.

Eyassu S. 2007. Handling, preservation and utilization of camel milk and camel milk products in Shinile and Jijiga Zones, eastern Ethiopia. Livest. Res. Rural Dev. 2016;19(6). from http://www.lrrd.org/lrrd19/6/seif19086.htm.

FAOSTAT 2015. World camel population. At http://faostat3.fao.org/browse/Q/QA/E. Accessed 12 Feb 2016.

Gadaga TH, Nyanga LK, Mutukumira AN. The occurrence, growth and control of pathogens in african fermented foods. Afr J Food Agric Nutr Dev. 2004;4:1.

Guliye AY, Noor IM, Bebe BO, Koskey IS. Role of camels (Camelusdromedarius) in the traditional lifestyle of Somali pastoralists in northern Kenya. Outlook Agric. 2007;36(1):29-34.

International Dairy Federation (I.D.F.). 1990. Handbook on milk collection in warm developing countries. IDF Bulletin special issue 9002

Karagözlü N, Karagözlü C, Ergönül B. Survival characteristics of E. coli O157:H7, S. typhimurium and S. aureusduring kefir fermentation. Czech J Food Sci. 2007; 25:202-7.

KEBS. 2007. Raw whole camel milk — Specification, KS 2061:2007 (confirmed 2013). Kenya

Lefoka Mamajoro. 2009. Survival of microbial pathogens in dairy products. Msc dissertation, University of the Free State. scholar.ufs.ac.za:8080/xmlui/ bitstream/handle/.../LefokaM.pdf?. Accessed 14 Oct 2016.

Loralyn H. Ledenbach and Robert T. Marshall. 2009. Microbiological spoilage of dairy products. Compendium of the microbiological spoilage of foods and beverages, $p, 27$.

Lore TA, Samuel KM, John W. Enumeration and identification of microflora in Suusac, a Kenyan traditional fermented camel milk produc. Lebensm-WissuTechnol. 2005:38:125-30. marketing practices in an emerging peri-urban production system in Isiolo County, Kenya. Pastoralism: Research, Policy and Practice, 3:28.

Matofari JW, Shalo PL, Younan M, Nanua NJ, Adongo A, Qabale A, Misiko BN. Analysis of microbial quality and safety of camel (Camelus dromedarius) milk chain and implications in Kenya. J Agric Ext Rural Dev. 2013:5(3):50-4.

Momanyi S. and Jenet A. 2010. Study on hygiene practices and market chain of milk and milk products in Somalia. http://fex.ennonline.net/39/study.aspx. Accessed 14 Oct 2016.

Mulwa WD, Schelling E, Wangoh J, Imungi KJ, Farah Z, Meile L. Microbiological quality of raw camel milk across the Kenyan market chain. Global Sci Book. 2011;5(1):79-83.

Musinga M., Kimenye D. and Kivolonzi P. 2008. The Camel Milk Industry in Kenya http://www.ebpdn.org/download/download.php?table. Accessed 14 Oct 2016.

Noor IM, Bebe OB, Abdi YG. Analysis of an emerging peri-urban camel production in Isiolo County, Northern Kenya. J Camelid Sci. 2012:5:41-61.

Noor I.M., Gulye A.Y., Tariq M. And Bebe B.O. 2013. Assessment of camel and camel milk

Odongo N. O, Lamuka P. O, Abong G. O, Matofari J. W, Abey K. A. 2016. Physiochemical and Microbiological Post-Harvest Losses of Camel Milk Due Deterioration Along the Camel Milk Value Chain in Isiolo, Kenya. Current Research in Nutrition and Food Science; 4(2)

Patricia Curiff. 1995. Official Methods of Analysis of AOAC International 16th Edition. Virginia, USA: AOAC International; p 108-110.

Paula Ana FC, Daniel JD, Renata W, Adriano B. Hydrolytic potential of a psychrotrophic Pseudomonas isolated from refrigerated raw milk. Braz J Microbiol. 2011:42:1479-84.

Perko B. Effect of prolonged storage on microbiological quality of raw milk. Mljekarstvo. 2011;61(2):114-24.

Rochelle-Newall E, Nguyen TMH, Le TPQ, Sengtaheuanghoung O, Ribolzi O. A short review of fecal indicator bacteria in tropical aquatic ecosystems: knowledge gaps and future directions. Front Microbiol. 2015;6:308. 
Samaržija D, Šimun Z, Tomislav P. Psychrotrophic bacteria and milk and dairy products quality. Mljekarstvo. 2012;62(2):77-95.

Wanjohi, GM, CG Gitao, and LC Bebora. 2010. The hygienic quality of camel milk marketed from North Eastern Province of Kenya and how it can be improved. Garissa: A paper presented at International Camel Symposium Wayua FO, Okoth MW, Wangoh J. Survey of post-harvest handling, preservation and processing practices along camel milk chain In Isiolo District, Kenya. Afr J Food Agric NutrDev. 2012;12(7):6897-912.

\section{Submit your manuscript to a SpringerOpen ${ }^{\circ}$ journal and benefit from:}

- Convenient online submission

- Rigorous peer review

- Immediate publication on acceptance

- Open access: articles freely available online

- High visibility within the field

- Retaining the copyright to your article

Submit your next manuscript at springeropen.com 